\title{
PENGARUH MOTIVASI KERJA DAN KEPUASAN KERJA TERHADAP KINERJA GURU SMK MUHAMMADIYAH SALATIGA
}

\author{
Reza Ahmadiansah \\ Mahasiswa Pascasrjana Magister Sains Psikologi UKSW \\ oblonk.reza07@gmail.com
}

\begin{abstract}
The influence of work motivation and job satisfaction are very important in influencing the performance. This study was aimed to assess the effect of motivation and job satisfaction conducted to the teachers of Muhammadiyah Vocational School (SMK) of Salatiga performances with the total sample of 52 teachers. From the data analysis, it shows that the effect of motivation and job satisfaction to teachers performance in Muhammadiyah Vocational School (SMK) of Salatiga is significant with the significance of 0,003 $<0,05 . F_{\text {value }}$ of 6,378, and effective contribution of $20,7 \%$.
\end{abstract}

Keywords: influence, motivation, performance

\begin{abstract}
Abstrak
Pengaruh motivasi dan kepuasan bekerja merupakan suatu hal penting yang mempengaruhi kinerja. Penelitian ini ditujukan untuk menguji efek motivasi dan kepuasan bekerja pada kinerja guru SMK Muhammadiyah Salatiga dengan total sampel sejumlah 52 guru. Dari analisis data menunjukkan bahwa efek motivasi dan kepuasan bekerja pada kinerja guru di SMK Muhammadiyah Salatiga adalah signifikan dengan signifikansi $0,003<0,05 . \mathrm{F}_{\text {value }}$ of 6,378 , dengan kontribusi efektif sebesar $20,7 \%$.
\end{abstract}

Kata Kunci: Motivasi, Kepuasan, Kinerja

\section{Pendahuluan}

Kinerja guru merupakan perwujudan kerja yang dilakukan oleh seorang guru. Kinerja guru yang baik merupakan suatu langkah untuk menuju tercapainya tujuan pendidikan. Mangkunegara (2011:67) mengemuka-kan kinerja adalah hasil kerja secara kualitas dan kuantitas yang dicapai seseorang dalam melaksanakan tugasnya sesuai dengan tanggung jawab yang diberikan kepadanya. Apabila dikaitkan dengan guru, maka dapat dikatakan bahwa kinerja guru adalah hasil kerja yang dicapai guru dalam melaksanakan tugas-tugas yang dibebankan kepadanya.

Kinerja guru yang optimal dipengaruhi oleh berbagai faktor, baik internal maupun eksternal, antara lain: pengalaman kerja, keterampilan teknis, tingkat pendidikan, gaya kepemimpinan kepala sekolah, motivasi kerja, dan kepuasan kerja. Sebagai-mana diungkapkan oleh Robbins (2001:184), bahwa kinerja juga dapat dipengaruhi oleh kemangkiran, komitmen, kompetensi, produktivitas, motivasi, dan kepuasan kerja. 
Ada berbagai faktor yang mempengaruhi kinerja individu. Menurut Gibson (dalam Cokroaminoto, 2007), kinerja individual karyawan dipengaruhi oleh faktor motivasi, kemampuan dan lingkungan kerja. Faktor motivasi memiliki pengaruh langsung dengan kinerja individual karyawan. Sedangkan faktor kemampuan individual dan lingkungan kerja memiliki pengaruh yang tidak langsung dengan kinerja. Kedua faktor tersebut keberadaannya akan mempengaruhi motivasi kerja karyawan. Apabila hal ini dikaitkan dengan kinerja guru, maka motivasi kerja mempunyai pengaruh langsung dengan kinerja guru. Sedangkan Mangkuprawiro (2007) menjelaskan, bahwa kinerja individu dipengaruhi oleh kepuasan kerja. Kepuasan kerja itu sendiri adalah perasaan individu terhadap pekerjaannya. Perasaan ini berupa suatu hasil penilaian mengenai seberapa jauh pekerjaannya secara keseluruhan mampu memuaskan kebutuhannya.

Sejalan dengan apa yang diungkapkan oleh Gibson dan Mangkuprawiro, Yudianto (2008) yang melakukan penelitian tentang "Pengaruh Kepuasan Kerja dan Motivasi Kerja Terhadap Kinerja Guru Di SMK Pangudi Luhur Tarcisius Semarang" menemukan bahwa ada pengaruh yang signifikan antara motivasi kerja terhadap kinerja guru. Demikian pula halnya dengan Varadila (2010) yang melakukan penelitian dengan judul "Pengaruh Motivasi Kerja Guru dan Gaya Kepemimpinan Kepala Sekolah terhadap Kinerja Guru di SMK Ardjuna 1 Malang" menemukan bahwa motivasi kerja guru berpengaruh terhadap kinerja guru di SMK Ardjuna 1 Malang.

Berbeda dengan hasil penelitian yang dilakukan oleh Yudianto dan Varadila, Usman (2011) yang melakukan penelitian dengan judul "Pengaruh kemampuan, motivasi kerja, kepemimpinan kepala sekolah, iklim organisasi dan kepuasan kerja terhadap kinerja guru ekonomi SMKN di Surabaya" menemukan bahwa motivasi kerja tidak berpengaruh terhadap kinerja guru ekonomi SMK Negeri di Surabaya.

Oleh karena itu usaha meningkatkan kinerja guru perlu dikondisikan oleh kepala sekolah atau lembaga penyelenggara pendidikan. Sekolah Menengah Kejuruan (SMK) Muhammadiyah Salatiga yang menyelenggarakan pendidikan menengah kejuruan juga mempunyai kewajiban untuk meningkatkan kinerja guru yang melaksanakan proses kegiatan belajar mengajar di sekolah. Oleh karena itu penelitian ini diarahkan untuk mengkaji lebih jauh tentang pengaruh motivasi kerja dan kepuasan kerja terhadap kinerja guru yang bekerja di Sekolah Menengah Kejuruan Muhammadiyah Salatiga. 
Reza Ahmadiansah, Pengaruh Motivasi Kerja Dan Kepuasan Kerja...

\section{Permasalahan}

Masalah yang ingin dikaji dalam penelitian ini adalah (1) apakah ada pengaruh motivasi kerja terhadap kinerja guru SMK Muhammadiyah Salatiga? (2) apakah ada pengaruh kepuasan kerja terhadap kinerja guru SMK Muhammadiyah Salatiga?

\section{Kinerja dan Indikator Kinerja Guru}

Puspitasari (2011) memberikan pengertian kinerja guru sebagai hasil kerja dari seorang guru dalam menjalankan tugas pokoknya sebagai pendidik meliputi merencanakan pembelajaran, melaksanakan pembelajaran, menilai hasil pembelajaran, membimbing dan melatih peserta didik, serta melaksanakan tugas tambahan yang melekat pada pelaksanaan tugas pokok. Sedangkan Pujiyanti dkk. (2013) memberikan pengertian kinerja guru sebagai hasil kerja yang telah dicapai oleh seorang guru dalam menjalankan tugasnya sesuai dengan tanggung jawab dan tugas yang diberikan, yaitu menyelenggarakan pem-belajaran sesuai dengan prinsip-prinsip profesionalitas serta mencapai tujuan pendidikan nasional.

Bahwa aspek-aspek kinerja yang dapat dijadikan sebagai standar penilaian adalah: (1) Kualitas kerja yakni berkaitan dengan keterampilan, ketelitian, kerapian, dan kesesuaian hasil pekerjaan yang dihasilkan dalam kurun waktu tertentu. (2) Kuantitas kerja yaitu jumlah pekerjaan yang dihasilkan dalam kurun waktu tertentu, berkaitan dengan pelaksanaan tugas reguler dan tugas tambahan. (3) Sikap berkaitan dengan ketaatan mengikuti perintah, kebiasaan mengikuti peraturan, keselamatan, inisiatif, ketepatan waktu kehadiran, dan dapat menunjukkan seberapa jauh tanggung jawab terhadap pelaksanaan tugas, serta bagaimana tingkat kerja sama dengan teman dan atasan dalam menyelesaikan pekerjaan. (4) Ketepatan waktu yakni ketepatan waktu dalam menyelesaikan tugas berdasarkan standar kerja yang telah ditetapkan.

\section{Teori Kinerja}

Bernardin dan Russel (dalam Ruky, 2002:15) mendefenisikan kinerja sebagai berikut: "performance is defined as the record of outcomes produced on a specified job function or activity during time period. Prestasi atau kinerja adalah catatan tentang hasil-hasil yang diperoleh dari fungsi-fungsi pekerjaan tertentu atau kegiatan selama kurun waktu tertentu. Diungkapkan oleh VanScotter, et.al. (dalam Sonnentag \& Frese, 2002), bahwa kinerja adalah suatu prasyarat utama walaupun bukanlah satu-satunya untuk 
perkembangan karier di masa yang akan datang dan keberhasilan dalam pasar pekerja. Walaupun kemungkinan ada pengecualian, individu-individu yang berkinerja tinggi akan lebih mudah mendapatkan promosi dalam sebuah organisasi dan secara umum mempunyai kesempatan-kesempatan yang lebih baik dalam karier daripada mereka yang mempunyai kinerja rendah.

Campbell et.al. (dalam Sonnentag \& Frese, 2002) menyatakan, bahwa kinerja adalah suatu pekerjaan yang dilakukan oleh seseorang yang dipekerjakan oleh suatu organisasi, dan orang tersebut melakukannya dengan baik. Oleh karena itu, kinerja tidak hanya ditentukan oleh tindakan saja, tetapi juga oleh proses-proses penilaian dan evaluatif. Lebih dari itu, hanya tindakan-tindakan yang dapat ditimbang atau diukur atau dibuat skalanya yang dianggap merupakan kinerja.

Ditambahkan oleh Sonnentag et.al. (2002) bahwa para penulis setuju ketika sedang mengkonseptualisasikan kinerja, seseorang harus membedakan antara aspek tindakan (misalnya, tingkah laku) dan aspek hasil dari kinerja. Aspek tingkah laku menunjuk kepada apa yang dilakukan oleh individu di dalam situasi pekerjaan, sedangkan aspek hasil mengacu kepada konsekuensi atau hasil dari tingkah laku individu. Tidak semua sikap/tingkah laku diklasifikasikan sebagai konsep kinerja, tetapi hanya tingkah laku yang relevan dengan tujuan-tujuan organisasi.

Dalam berbagai situasi, aspek tingkah laku dan hasil saling berhubungan secara empiris, tetapi aspek-aspek ini tidak benar-benar saling melengkapi. Aspek hasil juga bergantung kepada factor-faktor lain selain tingkah laku individu. Sebagai contoh, bayangkan seorang guru yang sedang mengajar pelajaran membaca yang sempurna (aspek tingkah laku dari kinerja), tetapi satu atau dua diantara murid-muridnya ternyata tidak mengalami kemajuan dalam keterampilan membaca karena kekurangan mereka dalam hal intelektual (aspek hasil dari kinerja).

Dalam prakteknya, mungkin sulit untuk menggambarkan aspek tindakan dari kinerja tanpa menghubungkannya dengan aspek hasil. Karena tidak semua tindakan seseorang memerlukan kriteria untuk mengevaluasi sampai tingkatan mana kinerja seseorang dapat memenuhi tujuan-tujuan organisasi. Memang sulit untuk membayangkan bagaimana cara mengkonsep-tualisasikan kriteria-kriteria semacam itu tanpa secara simultan mempertimbangkan aspek hasil dari kinerja pada saat yang bersamaan. Oleh karena itu, penekanan pada kinerja yang menjadi tindakan juga tidak benar-benar memecahkan masalahnya. 
Reza Ahmadiansah, Pengaruh Motivasi Kerja Dan Kepuasan Kerja...

\section{Kinerja Sebagai Konsep Multi Dimensional}

Kinerja adalah sebuah konsep yang multi-dimensional. Pada tingkatan yang paling dasar, Borman et.al. (dalam Sonnentag \& Frese, 2002) membedakan antara kinerja tugas dan kinerja kontekstual. Kinerja tugas menunjuk kepada kemampuan seorang individu yang dipergunakan untuk mengerjakan aktifitas-aktifitas yang memberi kontribusi pada 'inti teknis' dalam suatu organisasi.

Kontribusi ini bisa jadi secara langsung (misalnya, dalam kasus pekerja pada bagian produksi), atau secara tidak langsung (misalnya, dalam kasus para manajer atau personil staff). Kinerja kontekstual menunjuk kepada aktifitas-aktifitas yang tidak memberi kontribusi pada inti teknis, tetapi yang mendukung lingkungan organisasi, sosial, dan psikologis di mana tujuan-tujuan organisasi dicapai. Kinerja kontekstual meliputi tidak hanya tingkah laku seperti menolong rekan-rekan kerja atau menjadi anggota yang dapat dipercaya dari suatu organisasi, tetapi juga memberikan masukan saran-saran untuk peningkatan prosedur pekerjaan.

Borman, et.al. (dalam Sonnentag \& Frese, 2002) mengungkapkan tiga asumsi mendasar yang dihubungkan dengan perbedaan antara kinerja tugas dan kinerja kontekstual yaitu: (1) aktifitas-aktifitas yang relevan untuk kinerja tugas pada suatu pekerjaan berbeda dengan pekerjaan yang lain, sedangkan pada aktifitas-aktifitas kinerja kontekstual relatif sama antara pekerjaan yang satu dengan yang lain; (2) kinerja tugas berhubungan dengan kemampuan, sedangkan kinerja kontekstual berhubungan dengan kepribadian dan motivasi; (3) kinerja tugas merupakan sesuatu yang sudah ditentukan dan meliputi tingkah laku dalam peran (sebagai pekerja/anggota organisasi), sedangkan kinerja kontekstual tergantung pada kebijaksanaan masing-masing karyawan dan meliputi tingkah laku di luar peran.

\section{Motivasi Kerja}

Secara umum, Dinham dan Scott (dalam Karavas, 2010) menyatakan, bahwa motivasi menunjuk kepada sebuah stimulus terhadap tingkah laku dan tindakan, sebuah dorongan dari dalam yang menginspirasi untuk bertindak dalam jalur sebuah konteks tertentu. Sedangkan menurut Martoyo (2007:149) motivasi kerja adalah sesuatu yang menimbulkan dorongan atau semangat kerja, atau dengan kata lain pendorong semangat kerja. Tidak berbeda dengan Martoyo, As'ad (2008:45) juga mendefinisikan motivasi kerja sebagai sesuatu yang menimbulkan semangat atau dorongan kerja. Pendapat lain 
diberikan oleh Wijono (2010), yang mengatakan bahwa motivasi kerja adalah suatu kesungguhan atau usaha dari individu untuk melakukan pekerjaannya guna mencapai tujuan organisasi di samping tujuannya sendiri. Sedangkan McCormick (dalam Mangkunegara, 2011) mengungkapkan, bahwa motivasi kerja adalah kondisi yang berpengaruh membangkitkan, mengarahkan dan memelihara perilaku yang berhubungan dengan lingkungan kerja. Dengan demikian dapat disimpulkan, bahwa motivasi kerja adalah sesuatu yang menimbulkan dorongan untuk melakukan pekerjaan yang mengarah pada tercapainya suatu tujuan.

\section{Dimensi dan Indikator Motivasi Kerja}

Penelitian McClelland juga menunjukkan bahwa sampai pada tingkatan tertentu, para manajer dapat meningkatkan kebutuhan prestasi dari anak buahnya dengan menciptakan lingkungan kerja yang layak -memberi kesempatan bagi bawahannya untuk mengukur tingkat kemandirian, meningkatkan rasa tanggung jawab dan otonomi, secara bertahap membuat tugas-tugas jadi lebih menantang, dan memuji serta menghargai prestasi yang tinggi. McClelland menyebut aspek dari motivasi manajerial ini sebagai kebutuhan akan kekuasaan atau need for power (nPow).

Kebutuhan akan prestasi yang tinggi juga dapat dipicu oleh rasa takut akan kegagalan dalam diri seseorang. Para manajer mungkin mempunyai motivasi yang kuat untuk mengambil tindakan karena ketakutan mereka akan kegagalan dalam mencapai tujuan-tujuan pribadi maupun organisasi dan ketakutan mereka terhadap kemungkinan akan dipermalukan di depan banyak orang ketika kegagalan-kegagalan mereka diketahui. Sebaliknya, bagi beberapa individu, ketakutan akan keberhasilan dapat menjadi motif. Beberapa orang mungkin menyimpan rasa takut terhadap tekanan dan beban dari kesuksesan dan juga kecemburuan serta rasa tidak suka yang mungkin timbul pada orang lain.

\section{Kepuasan Kerja}

Martoyo (2007:142) mengemukakan bahwa kepuasan kerja (job satisfaction) adalah keadaan emosional karyawan, di mana terjadi ataupun tidak terjadi titik temu antara nilai balas jasa kerja karyawan dari perusahaan/organisasi dengan tingkat nilai balas jasa yang memang diinginkan oleh karyawan yang bersangkutan. Balas jasa karyawan dapat berupa uang (financial) maupun bukan uang (non financial). Sedangkan 
Reza Ahmadiansah, Pengaruh Motivasi Kerja Dan Kepuasan Kerja...

Robbins \& Judge (2008:113), menjelaskan bahwa kepuasan kerja (job satisfaction) merupakan suatu perasaan positif tentang pekerjaan seseorang yang merupakan hasil dari sebuah evaluasi karakteristiknya. Sementara itu Wijono (2011), mengemukakan bahwa kepuasan kerja sebagai suatu tingkat emosi yang positif dan menyenangkan individu. Handoko (2012), juga memaparkan bahwa kepuasan kerja (job satisfaction) adalah keadaaan emosional yang menyenangkan atau tidak menyenangkan dengan memandang pekerjaan mereka.

Kepuasan kerja mencerminkan perasaan seseorang terhadap pekerjaannya. Munandar (dalam Andri dkk., 2009) mengungkapkan, bahwa kepuasan kerja dapat dijelaskan sebagai penilaian seorang karyawan terhadap kesesuaian antara keinginan dengan hasil yang didapat. Karyawan akan merasa puas bila tidak ada perbedaan antara yang diharapkan dengan persepsinya atas kenyataan. Apabila yang didapat ternyata sama atau lebih besar dari yang diharapkan maka orang akan puas atau lebih puas. Sebaliknya, semakin jauh kenyataan yang dirasakan oleh karyawan hingga di bawah standar minimum, maka makin besar pula ketidakpuasan seorang karyawan terhadap pekerjaan yang dilakukannya.

\section{Aspek dan Indikator Kepuasan Kerja}

Aspek-aspek kepuasan kerja guru meliputi keterlibatan guru dalam membuat keputusan sekolah, pengakuan yang dirasakan guru, harapan guru, hubungan antar personil yang terjadi dalam lingkungan kerja dan lingkungan kerja yang menyenangkan. Aspek-aspek kepuasan kerja guru ini akan dijadikan alat ukur untuk mengukur variabel kepuasan kerja guru, dengan pertimbangan bahwa aspek-aspek tersebut sesuai dengan kebutuhan guru, dimana dalam melakukan aktivitas kegiatan proses belajar mengajar, di antaranya berupa mempersiapkan materi pengajaran, mengajar di kelas, ataupun melakukan evaluasi dari hasil belajar siswa, sudah barang tentu seorang guru mempunyai harapan akan mendapatkan imbalan dari pihak sekolah yang menyelenggarakan kegiatan pendidikan.

Kepuasan guru terhadap pekerjaan akan tumbuh bilamana pekerjaan, gaji, peluang promosi, dan lingkungan kerja di sekolah mampu memberikan rasa senang. Dengan pekerjaan yang membanggakan, gaji yang memadai, peluang promosi yang terbuka, dan lingkungan kerja yang kondusif akan memberikan kepuasan bagi guru 
Inject, Interdisciplinary Journal of Communication, Vol. 1, No. 2, Desember 2016:223-236

dalam menjalani profesinya. Apabila kebutuhan-kebutuhan tersebut dipenuhi bukan tidak mungkin akan memicu timbulnya kinerja yang tinggi.

\section{Efek Kepuasan Kerja}

Kepuasan kerja individu memiliki peran yang cukup besar di dalam pencapaian tujuan organisasi. Individu yang mempunyai kepuasan kerja yang tinggi mempunyai sikap yang positif terhadap pekerjaannya, sedangkan individu yang tidak berpuas hati mempunyai sikap yang negatif terhadap pekerjaannya. Kepuasan dan ketidakpuasan kerja individu akan berpengaruh terhadap kinerja individu yang pada akhirnya akan berpengaruh terhadap pencapaian tujuan organisasi. Menurut Strauss dan Sayles dalam Handoko (2001), individu yang tidak memperoleh kepuasan kerja tidak akan pernah mencapai kematangan psikologi dan pada gilirannya akan menjadi frustasi. Individu akan sering melamun, semangat kerja rendah, cepat lelah dan bosan, emosinya tidak stabil, sering absen dan melakukan sesuatu yang tidak berhubungan dengan pekerjaannya. Sedangkan individu yang mendapatkan kepuasan kerja biasanya mempunyai catatan kehadiran yang lebih baik.

Kepuasan kerja secara umum menyangkut sikap seseorang mengenai pekerjaannya. Karena menyangkut sikap, pengertian kepuasan kerja mencakup berbagai hal seperti kondisi dan kecenderungan perilaku seseorang. Kepuasan itu tidak tampak nyata, tetapi dapat diwujudkan dalam suatu hasil pekerjaan. Pada dasarnya kepuasan atau ketidakpuasan kerja seseorang akan menjadi umpan balik yang akan mempengaruhi kinerja orang tersebut dimasa yang akan datang. Jadi hubungan antara kepuasan kerja dan kinerja menjadi suatu sistem yang berlanjut. Oleh sebab itu, kepuasan kerja diperlukan untuk meningkatkan kinerja individu.

Kepuasan kerja berkenaan dengan kesesuaian antara harapan seseorang dengan imbalan yang disediakan. Kepuasan kerja individu berdampak pada prestasi kerja, disiplin, dan kualitas kerja. Pada diri individu yang puas terhadap pekerjaanya kemungkinan akan berdampak positif terhadap peningkatan mutu pekerjaannya. Demikian sebaliknya, jika kepuasan kerja individu rendah maka akan berdampak negatif terhadap perkembangan mutu pekerjaannya. Individu yang membolos, malas, mogok kerja, sering mengeluh, merupakan tanda adanya ketidakpuasan dalam bekerja.

Ada konsekuensi ketika karyawan menyukai pekerjaan mereka, dan ada konsekuensi ketika karyawan tidak menyukai pekerjaan mereka. Robbins \& Judge 
Reza Ahmadiansah, Pengaruh Motivasi Kerja Dan Kepuasan Kerja...

(2008) menyodorkan sebuah kerangka teoretis, yaitu kerangka keluar-aspirasi-kesetiaanpengabaian dengan penjelasan sebagai berikut: Pertama, keluar ketidakpuasan yang diungkapkan melalui perilaku yang ditujukan untuk meninggalkan organisasi, termasuk mencari posisi baru dan mengundurkan diri. Kedua, aspirasi ketidakpuasan yang diungkapkan melalui usaha-usaha yang aktif dan konstruktif untuk memperbaiki kondisi, termasuk menyarankan perbaikan, mendiskusikan masalah dengan atasan, dan beberapa bentuk aktivitas serikat kerja. Ketiga, kesetiaan ketidakpuasan yang diungkapkan secara pasif menunggu membaiknya kondisi, termasuk membela organisasi ketika berhadapan dengan kecaman eksternal dan mempercayai organisasi dan manajemennya untuk melakukan hal yang benar. Keempat, pengabaian ketidakpuasan yang diungkapkan dengan membiarkan kondisi menjadi lebih buruk, termasuk ketidakhadiran atau keterlambatan terus-menerus, kurangnya usaha, dan meningkatnya kesalahan.

Ditambahkan oleh Robbins \& Judge (2008), bahwa karyawan yang puas cenderung berbicara positif tentang organisasinya, membantu individu lain, dan melewati harapan normal dalam pekerjaan mereka. Selain itu, karyawan yang puas cenderung lebih ramah, ceria, dan responsif.

\section{Kepuasan Kerja (Discrepancy Theory)}

Locke (dalam Wijono, 2007) melihat kepuasan atau ketidakpuasan dari dua nilai (values) yaitu (1) pertentangan yang dipersepsikan antara apa yang diinginkan dengan apa yang diterima dalam kenyataan, dan (2) apa pentingnya pekerjaan yang diinginkan. Kepuasan kerja secara keseluruhan bagi individu adalah jumlah dari kepuasan kerja setiap aspek pekerjaan dikalikan dengan derajat pentingnya aspek pekerjaan individu.

Individu akan terpuaskan jika tidak ada selisih antara kondisi-kondisi yang diinginkan dengan kondisi aktual. Semakin besar kekurangan dan semakin banyak halhal penting yang diinginkan, semakin besar ketidakpuasannya. Kesimpulan yang dapat diambil adalah teori ketidaksesuaian menekankan selisih antara kondisi yang diinginkan dengan kondisi aktual (kenyataan), jika ada selisih jauh antara keinginan dan kekurangan yang ingin dipenuhi dengan kenyataan, maka orang menjadi tidak puas. Tetapi jika kondisi yang diinginkan dan kekurangan yang ingin dipenuhi ternyata sesuai dengan kenyataan yang didapat maka akan timbul rasa puas. 
Inject, Interdisciplinary Journal of Communication, Vol. 1, No. 2, Desember 2016:223-236

\section{Model dari Kepuasan Bidang atau Bagian (Facet Satisfaction)}

Kepuasan bidang menurut model Lawler (dalam Wijono, 2007) mengatakan bahwa individu akan merasa puas terhadap bidang tertentu dari pekerjaan mereka (misalnya, hubungan antara rekan sekerja, atasan dan bawahan, dan atau gaji). Individu dapat menerima dan melaksanakan pekerjaannya dengan senang hati dalam bidang yang dia persepsikan. Jumlah dari bidang yang dipersepsikan oleh individu akan menjadi sesuai tergantung dari bagaimana individu tersebut mem-persepsikan nilai dari pekerjaan dan karakteristik pekerjaannya. Jumlah dari bidang yang dipersepsikan orang terhadap apa yang individu terima secara nyata tergantung dari hasil output yang secara nyata individu terima dan hasil output yang dipersepsikan dari orang dengan siapa individu akan membandingkan dirinya.

Dengan kata lain kepuasan individu didasarkan pada persepsi individu terhadap keadilan atau kewajaran imbalan yang diterima. Keadilan diartikan sebagai perbandingan antara input (misalnya: pendidikan guru, pengalaman mengajar, jumlah jam mengajar, banyaknya usaha yang dicurahkan pada sekolah) dengan output (misalnya, upah/gaji, penghargaan, promosi, kenaikan pangkat) dibandingkan dengan guru lain di sekolah yang sama atau di sekolah lain pada input dan output yang sama.

\section{Teori Proses Bertentangan (Opponent-Process Theory)}

Teori proses bertentangan oleh Landy (dalam Wijono, 2007) memberi tekanan bahwa individu ingin mempertahankan keseimbangan emosional. Teori ini mengasumsikan bahwa kondisi emosional yang berlebihan tidak akan memberikan kemaslahatan. Teori ini menjelaskan bahwa jika individu memperoleh keberhasilan dalam pekerjaannya, maka individu tersebut akan merasa senang sekaligus takut gagal atau tidak senang (yang lebih lemah). Setelah beberapa saat perasaan senang dan bangga akan berangsur-angsur turun dan semakin melemah sehingga individu akan merasa takut gagal sebelum kembali dalam kondisi yang normal. Hal ini terjadi karena emosi tidak senang (emosi yang berlawanan) berlangsung lama.

\section{Metode Penelitian}

Metode penelitian yang digunakan dalam penelitian ini adalah dengan pendekatan kuantitatif yang terbagi atas dua bagian yaitu; a) metode penelitian, meliputi: uraian dan jumlah variabel yang akan digunakan dalam penelitian, definisi operasional yang akan memberikan informasi tentang bagaimana caranya mengukur variabel, teknik 
Reza Ahmadiansah, Pengaruh Motivasi Kerja Dan Kepuasan Kerja...

pengumpulan data, validitas dan reliabilitas alat ukur, penentuan populasi dan sampel; b) teknik analisis data, meliputi: uji asumsi dan cara pengujian hipotesis. Adapun sampel yang digunakan dalam penelitian ini berupa sampel jenuh yaitu sebanyak 52 guru. Hal ini didasarkan pada pendapat Arikunto (2009:95) yang menyebutkan bahwa jika anggota subjek dalam populasinya hanya meliputi 100 hingga 150 atau kurang dari 100, dan dalam pengumpulan menggunakan angket maka sebaiknya subjek sejumlah itu diambil seluruhnya. Demikian penelitian ini bermanfaat untuk generalisasi dengan kesalahan yang sangat kecil.

\section{Pembahasan dan Hasil Penelitian}

Hipotesis penelitian ini menyatakan terdapat pengaruh yang signifikan antara motivasi kerja dan kepuasan kerja terhadap kinerja guru. Hasil penelitian diperoleh nilai F hitung sebesar 6,378 lebih besar dari nilai $F$ tabel 3,186 dengan tingkat signifikansi $0,003<0,05$. Hal ini menunjukkan adanya pengaruh yang positif dan signifikan antara motivasi kerja dan kepuasan kerja terhadap kinerja guru. Artinya variabel motivasi kerja dan kepuasan kerja berperan terhadap munculnya kinerja guru. Dengan demikian hipotesis yang diajukan dinyatakan diterima. Hasil ini sejalan dengan hasil penelitian yang dilakukan oleh Yudianto (2008) yang menemukan adanya pengaruh yang signifikan antara kepuasan kerja dan motivasi kerja terhadap kinerja guru.

Seorang guru yang melakukan aktivitas mengajar dikarenakan ada motivasi yang mendasarinya. Memotivasi berarti memberi motif atau memberi dorongan. Motivasi dapat pula diartikan faktor yang mendorong orang untuk bertindak dengan cara tertentu. Sedangkan motivasi kerja adalah dorongan yang menyebabkan seorang guru bersedia melakukan kegiatan mengajar. Guru dalam melaksanakan tugas mengajar di sekolah memerlukan motivasi baik dari faktor eksternal maupun internal. Motivasi guru dalam mengajar berupa intensitas (kesungguhan dan ketekunan) yang tinggi dalam melaksanakan tugas mengajar, guru akan berusaha meningkatkan kemampuan diri untuk selalu menampilkan pelayanan yang lebih baik dalam mengajar dan guru mempunyai tanggung jawab moral.

Motivasi merupakan dorongan individu untuk menjadi yang terbaik dalam menjalankan suatu tugas atau dalam melaksanakan tanggung jawabnya. Guru yang memiliki motivasi tinggi akan senantiasa bekerja dengan maksimal, menaati apa yang menjadi peraturan organisasi dan berusaha menunjukkan yang terbaik bagi 
organisasinya serta memiliki tanggung jawab yang besar atas tugas-tugasnya. Motivasi yang tinggi juga akan mendorong guru mengembangkan kreativitas dan mengaktualkan semua kemampuan serta energi yang dimilikinya demi mencapai kinerja yang maksimal.

Menurut Mc.Clellen dalam Stoner dan Freeman (1992:446) bahwa ada tiga kebutuhan manusia yaitu: kebutuhan akan prestasi needs for achievement, kebutuhan akan afiliasi needs for affiliation, dan kebutuhan akan kekuasaan needs for power. Hal tersebut mengindikasikan suatu kebutuhan yang kuat akan prestasi berhubungan dengan seberapa tinggi individu-individu termotivasi untuk mengerjakan dengan baik tugastugas pekerjaan mereka. Jadi, individu yang mempunyai kebutuhan yang tinggi akan prestasi (need for Achievement) cenderung sangat termotivasi oleh situasi kerja yang menantang dan kompetitif. Ditambahkan oleh Manullang (1981) dalam Mahesa (2010), bahwa seseorang yang memiliki kebutuhan untuk berprestasi (need for achievement) akan mempunyai keinginan yang kuat untuk mencapai keberhasilan atau kepuasan. Dengan demikian dapat dikatakan bahwa motivasi berkaitan dengan kepuasan.

Temuan dalam penelitian ini tentang kinerja guru terdapat 13 responden $(25 \%)$ mempunyai kinerja dengan kategori sangat tinggi dan 38 responden $(73,08 \%)$ mempunyai kinerja dengan kategori tinggi. Sedangkan 1 responden $(1,92 \%)$ mempunyai kinerja dengan kategori cukup. Kinerja guru yang termasuk dalam kategori sangat tinggi dan tinggi, tidak lepas dari kemampuan dan kemauan guru untuk bekerja dengan sungguh-sungguh, di mana kemauan dan kemampuan ini merupakan motivasi intrinsik atau motivasi yang berasal dari dalam diri guru itu sendiri. Penelitian ini juga menemukan 7 responden $(13,46 \%)$ mempunyai motivasi kerja dengan kategori sangat tinggi, 37 responden $(71,15 \%)$ mempunyai motivasi kerja dengan kategori tinggi, dan 8 responden $(15,39 \%)$ mempunyai motivasi kerja dengan kategori cukup. Tingginya motivasi kerja yang dimiliki oleh guru SMA Muhammadiyah tidak terlepas dari faktor-faktor yang mempengaruhi munculnya motivasi tersebut.

Hal di atas sejalan dengan pernyataan Robbin, S.P. (2001:187), bahwa kinerja sebagai fungsi interaksi antara kemampuan atau ability (A), motivasi atau motivation (M) dan kesempatan atau opportunity $(\mathrm{O})$, jadi kinerja $=f(\mathrm{~A} \times \mathrm{M} \times \mathrm{O})$. Artinya: kinerja merupakan fungsi dari kemampuan, motivasi dan kesempatan. Dengan demikian, kinerja ditentukan oleh faktor-faktor kemampuan, motivasi dan kesempatan. Seperti telah dijelaskan oleh Koontz (1990) bahwa motivasi mengacu pada dorongan dan upaya untuk memuaskan suatu keinginan atau tujuan, sedangkan kepuasan mengacu pada 
Reza Ahmadiansah, Pengaruh Motivasi Kerja Dan Kepuasan Kerja...

pengalaman yang menyenangkan pada saat terpenuhinya suatu keinginan. Dengan kata lain motivasi merupakan dorongan kearah suatu hasil sedangkan kepuasan merupakan hasil yang telah dicapai atau dialami. Dengan kata lain jika guru puas terhadap perlakuan organisasi sekolah, mereka akan terdorong untuk bekerja penuh semangat dan bertanggung jawab. Dari uraian di atas dapat disimpulkan bahwa motivasi kerja dan kepuasan kerja mempunyai pengaruh terhadap munculnya kinerja guru. Adapun besarnya sumbangan efektif yang dapat diberikan oleh variabel motivasi kerja dan kepuasan kerja guru terhadap kinerja guru adalah 20,7\%. Sisanya 79,3\% dijelaskan oleh variabel lain yang tidak diteliti dalam penelitian ini.

\section{Simpulan}

Temuan yang diperoleh dalam kajian penelitian tentang pengaruh motivasi kerja dan kepuasan kerja terhadap kinerja guru SMK Muhammadiyah Salatiga adalah: (1) Motivasi kerja berpengaruh positif dan signifikan terhadap kinerja guru SMK Muhammadiyah Salatiga. Hal ini dapat diketahui dari hasil uji Anova seperti tampak pada Tabel 4.10 yang menunjukkan nilai t hitung sebesar 2,354 dengan signifikansi sebesar $0,023<0,05$. Artinya apabila skor motivasi kerja meningkat terdapat kecenderungan diikuti oleh meningkatnya skor kinerja guru. Demikian pula sebaliknya apabila skor motivasi kerja menurun maka skor kinerja guru juga akan menurun. (2) Kepuasan kerja berpengaruh positif dan signifikan terhadap kinerja guru SMK Muhammadiyah Salatiga. Hal ini dapat diketahui dari hasil uji Anova seperti tampak pada Tabel 4.10 yang menunjukkan nilai t hitung sebesar 2,372 dengan signifikansi sebesar $0,022<0,05$. Artinya apabila skor kepuasan kerja meningkat terdapat kecenderungan diikuti oleh meningkatnya skor kinerja guru. Demikian pula sebaliknya apabila skor kepuasan kerja menurun maka skor kinerja guru juga akan menurun. (3) Skor rata-rata motivasi kerja, kepuasan kerja, dan kinerja guru SMK Muhammadiyah Salatiga termasuk dalam kategori tinggi.

\section{Daftar Pustaka}

Andri dan Waluyo, L.E.M. 2009. Harga diri, orientasi kontrol, dan kepuasan kerja karyawan. Jurnal Psikologi, 2(2).

Arikunto, S. 1990. Manajemen pengajaran secara manusiawi. Jakarta: Rineka Cipta.

As'ad, M. 2008. Psikologi industri. Liberty: Yogyakarta. 
Inject, Interdisciplinary Journal of Communication, Vol. 1, No. 2, Desember 2016:223-236

Gibson, J.L., Ivancevich, J.M., dan Donelly, Jr. J.H. (1991). Organisasi: perilaku, struktur, proses. Edisi Kelima. Alih Bahasa Djarkasih. Jakarta: Erlangga.

Handoko, T.H. 2012. Manajemen personalia dan sumber daya manusia. Yogyakarta, BPFE Press.

Karavas, E., 2010. How satisfied are Greek EFL teachers with their work? Investigating the motivation and job satisfaction levels of Greek EFL teachers. Porta Linguarum, National and Kapodistrian University of Athens.

Mangkunegara, A.P. 2011. Manajemen Sumber Daya Manusia Perusahaan. Bandung: PT. Remaja Rosdakarya.

Manulang, M. 1994. Management Personalia. Jakarta: Ghalia Indonesia.

Martoyo, Susilo, 2007. Manajemen Sumber Daya Manusia. Yogyakarta: BPFE

Pujiyanti \& Isroah. 2013. Pengaruh motivasi kerja dan disiplin kerja terhadap kinerja guru SMA Negeri 1 Ciamis. Journal UNY, Kajian Pendidikan Akuntansi Indonesia, 2(1), $184-207$.

Puspitasari, N. 2011. Hubungan antara motivasi berprestasi dengan kinerja guru di SMK Negeri 1 Magelang. Skripsi. Salatiga: Fakultas Psikologi Universitas Kristen Satya Wacana.

Robbin, P, Stephen, 2001. Perilaku Organisasi, Konsep, Kontroversi, Aplikasi. Jilid I dan II, Edisi Kedelapan, Jakarta: Prenhallindo.

Robbins, S.P., and Judge, T.A. 2008. Perilaku Organisasi. Edisi Kedua belas, Jakarta: Salemba Empat.

Usman, M. 2011. Pengaruh kemampuan, motivasi kerja, kepemimpinan kepala sekolah, iklim organisasi dan kepuasan kerja terhadap kinerja guru ekonomi SMKN di Surabaya. Disertasi. Tidak dipublikasikan. Program Studi Pendidikan Ekonomi, Program Pascasarjana Universitas Negeri Malang.

Wijono, S. 2011. Psikologi industri dan organisasi: dalam suatu bidang gerak psikologi sumber daya manusia. Kencana Prenanda Media Group.

Rensa, V.V. 2010. Pengaruh motivasi kerja guru dan gaya kepemimpinan kepala sekolah terhadap kinerja guru di SMK Ardjuna 1 Malang. Universitas Negeri Malang. Diakses 14-12-12, dari http://karya-ilmiah.um.ac.id/ index.php/ manajemen/ article/view/5145

Stoner James A.F., R. Edward Freeman. 1992. Management. United State of America: Prentice-Hall, Inc. 